\title{
Production and characterization of lipid microparticles produced by spray cooling encapsulating a low molar mass hydrophilic compound
}

\author{
Produção e caracterização de micropartículas lipídicas produzidas por spray cooling \\ encapsulando um composto hidrofílico de baixa massa molar
}

\author{
Alda Jusceline LEONEL ${ }^{1}$, Hulda Noemi Mamani CHAMBI ${ }^{1}$, Daniel BARRERA-ARELLANO ${ }^{2}$, \\ Heloise Oliveira PASTORE ${ }^{3}$, Carlos Raimundo Ferreira GROSSO ${ }^{1 *}$
}

\begin{abstract}
The objective of this research was to produce and characterize lipid particles (MpLs) that may be used as carriers of high amounts of hydrophilic core and evaluate the influence of the core amount on the performance of lipid microparticles. The MpLs were produced by spray cooling from solid and liquid lipid mixtures (stearic and oleic fatty acids and partly hydrogenated vegetable fat) containing glucose solution as core and soy lecithin as surfactant. The performance of MpLs was evaluated by means of the effective amount of encapsulated core, the core amount present on the surface of MpLs (superficial glucose) and the core release profile in aqueous solution. Morphological observations showed that MpLs presented spherical shape and a rugged and continuous surface, and an average diameter between 25 and $32 \mu \mathrm{m}$. The effective amount of encapsulated core was greater than $78 \%$ for all formulations evaluated. Larger amounts of superficial glucose were found in formulations in which more concentrated glucose solutions were used, regardless of the glucose lipid-solution ratio. The release results showed that core retention was significantly influenced by the glucose solution concentration, whereas release modulation was influenced by the glucose lipid-solution ratio.
\end{abstract}

Keywords: lipid microparticles; spray cooling; hydrophilic core release.

\section{Resumo}

O objetivo deste trabalho foi produzir e caracterizar partículas lipídicas (MpLs) que possam ser utilizadas como carreadores de altas quantidades de um recheio hidrofílico e avaliar a influência da quantidade de recheio sobre a performance das micropartículas. As MpLs foram produzidas por spray cooling a partir de misturas de ácidos graxos líquidos e sólidos (ácido esteárico e oléico) e gordura vegetal hidrogenada, contendo solução de glucose como recheio e lecitina de soja como surfactante. A performance das MpLs foi avaliada por meio da quantificação do recheio efetivamente encapsulado, da quantidade presente na superfície das MpLs e do perfil de liberação do recheio em meio aquoso. Observações morfológicas mostraram que as MpLs apresentaram forma esférica e superfície enrugada porém contínua, com um tamanho médio entre 25 e $32 \mu \mathrm{m}$. A quantidade efetivamente encapsulada foi superior a 78\% para todas as formulações avaliadas. Maior quantidade de glucose superficial foi observada nas formulações em que soluções mais concentradas de glucose foram utilizadas, independente da relação lipídiosolução. Os resultados da liberação mostraram que a retenção do recheio foi significativamente influenciada pela concentração de glucose utilizada, enquanto a modulação da liberação foi influenciada pela relação lipídio:solução de glucose.

Palavras-chave: micropartículas lipídicas; spray cooling; liberação de recheio hidrofílico.

\section{Introduction}

Microencapsulation is a coating technology that can be used to protect different compounds; control the release of this active material into a specific medium or place at a known rate, reduce the toxicity of the material and separate, from the formulation, compounds that are incompatible or reactive; among other purposes (SHAHIDI; HAN, 1993; RÉ, 1998).

The particle is composed of the compound to be protected (core), a surfactant - in the case where the wall materials and the core have opposite polarity - and the wall material, which is responsible for retaining and protecting the core (JACKSON; LEE, 1991). The surfactant is important in the core-wall material association, in the emulsion stability during the production of particles, in the physical stability during storage and in the release profile as well (SCHUBERT; HARMS; MÜLLERGOYMANN, 2006).

Among the various techniques used for the production of microparticles, spray cooling uses lipids as wall materials which are kept above their melting point temperatures - with the core being emulsified, solubilized or suspended in the melted lipid material and subsequently sprayed in a chamber with a temperature lower than that of the lipid melting point, thus producing lipid microparticles (MpLs) which are generally

Recebido para publicação em 26/12/2008

Aceito para publicação em 20/6/2009 (004009)

${ }^{1}$ Food and Nutrition Department, Faculty of Food Engineering, State University of Campinas - UNICAMP, CEP 13083-862, Campinas - SP, Brazil,

E-mail: grosso@fea.unicamp.br

${ }^{2}$ Food Technology Department, Faculty of Food Engineering, State University of Campinas - UNICAMP, CEP 13083-862, Campinas - SP, Brazil

${ }^{3}$ Chemistry Institute, State University of Campinas - UNICAMP, CEP 13083-862, Campinas - SP, Brazil

${ }^{*}$ A quem a correspondência deve ser enviada 
spherical and of a controllable size. It is a simple and low cost technique that can be used to encapsulate hydrophilic or hydrophobic compounds. The disadvantages of this technique include the low capacity of encapsulation, the possibility that part of the core is located on the surface of the particle, and the possibility of core expulsion due to the characteristic polymorphic rearrangements of lipid materials, in addition to the significant encapsulated water content in the case of emulsions (MEHNERT; MÄDER, 2001; MÜLLER, 2002a, b).

During lipid crystallization, the space available for the core filling will be reduced, which may also cause core expulsion. Crystallization occurs with more intensity when very similar or homogeneous lipid molecules are used, with long and perfect carbonic chains. These disadvantages led to the development of a new form of lipid particles called nanostructured lipid carriers (NLC), which are produced by a mixture of incompatible solid and liquid lipids that produce less ordered lipid matrices, resulting in a higher encapsulation capacity and a better release control (MÜLLER; RADTKE; WISSING, 2002a).

A review of the use of lipid particles to delivery bioactive food components has recently been published (WEISS; DECKER; McCLEMENTS, 2008), in which the authors pointed out the difficulties associated with the inclusion of hydrophobic compounds such as carotenoids, omega- 3 , fatty acids and phytosterols in food matrices; discussing also the main problems associated with the polymorphic properties on the stability of the particles. Lipid-based encapsulation systems are promising as they can be used to encapsulate and deliver low-molecular weight, water soluble nutrients such as riboflavin, glycine and tyrosine (ONAL; LANGDON, 2004); protein using a novel supercritical fluid process (RIBEIRO DOS SANTOS et al., 2002); enzymes such as $\beta$-galactosidase using fatty acid esters matrices (KWAK; IHM; AHN, 2001); citric acid using beeswax or carnauba wax matrices (MELLEMA et al., 2006) and casein or hydrolyzed casein or glucose solutions encapsulated in solid lipid microparticles (CHAMBI et al., 2008). Also glucose or bacto-peptone solutions encapsulated with milk fat were used as model systems with the aim of improving cheese ripening systems (MAGEE Jr.; OLSON, 1981).

The aim of this work was to produce and characterize lipid microparticles (MpLs) produced by spray cooling composed of stearic acid, oleic acid and partially hydrogenated vegetable fat as wall material, soy lecithin as surfactant, and glucose solution as the core material.

\section{Materials and methods}

\subsection{Material}

Stearic acid (Synth, São Paulo, Brazil); oleic acid (Synth, São Paulo, Brazil); partially hydrogenated vegetable fat (Mesa, Cia Leco de Produtos Alimentícios, São Paulo, Brazil); soy lecithin E322 (Caramuru Alimentos, Itumbiara, Goiás, Brazil); D-glucose anhydrous (Synth, São Paulo, Brazil).

\subsection{Methods}

\section{Lipid mixture}

The proportion of lipids used was chosen aiming at the production of solid microparticles at ambient temperature. A proportion of $2 / 1 / 1$ of stearic acid, oleic acid and hydrogenated vegetable fat (HVF) with a softening point of $49.3^{\circ} \mathrm{C}$ (AOCS, 1990) was used.

\section{Production of lipid microparticles}

The lipid/core material proportions $(\mathrm{p} / \mathrm{p})$ and glucose solution studied are shown in Table 1. The amount of lecithin was kept constant for all formulations ( $5 \%, \mathrm{p} / \mathrm{p}$ of lipid material). The lipid mixture was heated at $70{ }^{\circ} \mathrm{C}$ and, after complete fusion, the glucose solution was added. The mixture, kept at $70^{\circ} \mathrm{C}$, was homogenized in Ultraturrax T18 Basic (Ika, Rio de Janeiro, Brazil) for 5 minutes at $10000 \mathrm{rpm}$ and then sprayed with a $0.7 \mathrm{~mm}$ diameter double-fluid atomizer nozzle (Büchi, Flawil, Switzerland) also heated at $70{ }^{\circ} \mathrm{C}$ and air pressure of $1.0 \mathrm{kgf.cm}{ }^{-2}$. Atomization was done in a chamber (Ultratorac, LKB - Bromma, Germany) cooled at $10^{\circ} \mathrm{C}$. The samples were stored at $4.8^{\circ} \mathrm{C}$, in closed containers.

The particles obtained from the formulations studied (Table 1) were characterized as to their average size, surface morphology, encapsulation efficiency, superficial glucose amount, and glucose release in aqueous medium according to the following methods.

\section{Characterization of lipid microparticles}

\section{Surface morphology}

The samples were mounted onto aluminum stubs with a double sided copper tape and covered with a fine layer of gold in sputter Balzers (SCD50, Baltec, Liechtenstein) with a current of $40 \mathrm{~mA}$ for 180 seconds. Images were made by a Jeol scanning electron microscope (JMS-T300, Tokyo, Japan) with a voltage acceleration of $10 \mathrm{kV}$ and magnifications of $300 \times$ and $2500 \times$ according to Rosenberg and Lee (2004).

\section{Average size and size distribution of lipid microparticles}

Samples of each formulation were suspended in glycerol and observed by optical microscopy (Nikon Eclipse E800, Tokyo,

Table 1. Composition of formulations used in the production of lipid microparticles attained by spray cooling.

\begin{tabular}{cccc}
\hline Formulation & $\begin{array}{c}\text { Lipid/glucose } \\
\text { solution ratio }\end{array}$ & $\begin{array}{c}\text { Glucose solution } \\
\text { concentration (\%) }\end{array}$ & $\begin{array}{c}\text { g of glucose. } 100 \mathrm{~g}^{-1} \\
\text { of microparticles }\end{array}$ \\
\hline F1 & $90 / 10$ & 40 & 3.9 \\
F2 & $90 / 10$ & 60 & 5.6 \\
F3 & $90 / 10$ & 80 & 7.3 \\
F4 & $75 / 25$ & 40 & 9.4 \\
F5 & $75 / 25$ & 60 & 14.1 \\
F6 & $75 / 25$ & 80 & 19.2 \\
\hline
\end{tabular}


Japan). Images were acquired by the use of objectives of $10 \times$ and $20 \times$, and the average diameter ( 300 particles) was determined by the Image Pro Plus 4.0 software (CHAMBI et al., 2008).

\section{Evaluation of the Performance of lipid microparticles}

\section{Determination of superficial glucose}

An amount of $200 \mathrm{mg}$ of microparticles was weighed in a capped test tube and $10 \mathrm{~mL}$ of aqueous solution, containing $0.1 \%(\mathrm{p} / \mathrm{p})$ of Tween 80 . The tube was agitated for 10 seconds and its content filtered in filter paper. For glucose determination, aliquots of the filtered liquid were quantified (HENRY; CANNON; WILKEMAN, 1974) using a glucose determination kit (Laborlab, São Paulo, Brazil). Determinations were performed in triplicate.

Determination of total and effective encapsulation efficiencies

Total encapsulation efficiency was determined (MASCHKE et al., 2007) modified as follows: $12.4 \mathrm{~mL}$ of chloroform $(12.4 \mathrm{~mL})$ was added to a test tube containing 200 mg of microparticles; it was agitated in a Cole-Parmer super mixer for 10 seconds and let to rest for 10 minutes, twice. After the resting period, $12.4 \mathrm{~mL}$ of distilled water was added and a new agitation performed in the super mixer for 1 minute, with a resting period of 10 minutes. This step was repeated twice. The test tubes were centrifuged for 10 minutes at $15000 \mathrm{rpm}$ in a Sorvall Instruments (RC-5C, USA) centrifuge. Aliquots, withdrawn from the aqueous part of the mix, were analyzed for glucose determination as previously described. Determinations were performed in triplicate.

The effective encapsulation efficiency was calculated by subtracting the superficial glucose from the total glucose amount. The total value was compared against the initial amount used in the formulation. This ratio, expressed as a percentage, represents the effective encapsulation efficiency value.

\section{Microparticles release profile}

The glucose percentage released in water was determined after 0, 30, 60, 90 and 120 minutes, according to Chambi et al. (2008). For each determination, $200 \mathrm{mg}$ of microparticles was weighed in $10 \mathrm{~mL}$ of aqueous solution, containing $0.1 \%(\mathrm{p} / \mathrm{p})$ of Tween 80. The test tubes were kept under agitation in a Phoenix (AP-22, São Paulo, Brazil) test tube agitator and, at each time interval, the solution was filtrated in filter paper and the glucose determined as previously described. The tests and determinations, at each time, were performed in triplicate.

\section{Statistical analysis}

The data was statistically analyzed with the Tukey test by means of the Statistic 6.0 software (Statsofth Inc Tulsa, OK, USA). The differences among the means in the $95 \%$ confidence interval $(\mathrm{p}<0.05)$ were regarded as significant.

\section{Results and discussion}

\subsection{Characterization of lipid microparticles}

\section{Surface morphology}

The lipid microparticles were spherical, with rugged and continuous walls, presenting no cracks or holes. The size variation observed is characteristic of the atomization process used in the production of microparticles. Surface morphology was similar in all treatments evaluated. Details of the surface morphology of microparticles produced by the use of formulation 4 (Table 1) are shown in Figure 1.

The rugosity observed on the walls of microparticles seems to have been produced by the presence of stearic acid in the formulation as was previously observed by other authors (RODRIGUEZ et al., 1999; SAVOLAINEN et al., 2002). Eldem, Speiser and Hincal (1991) obtained microparticles with smooth
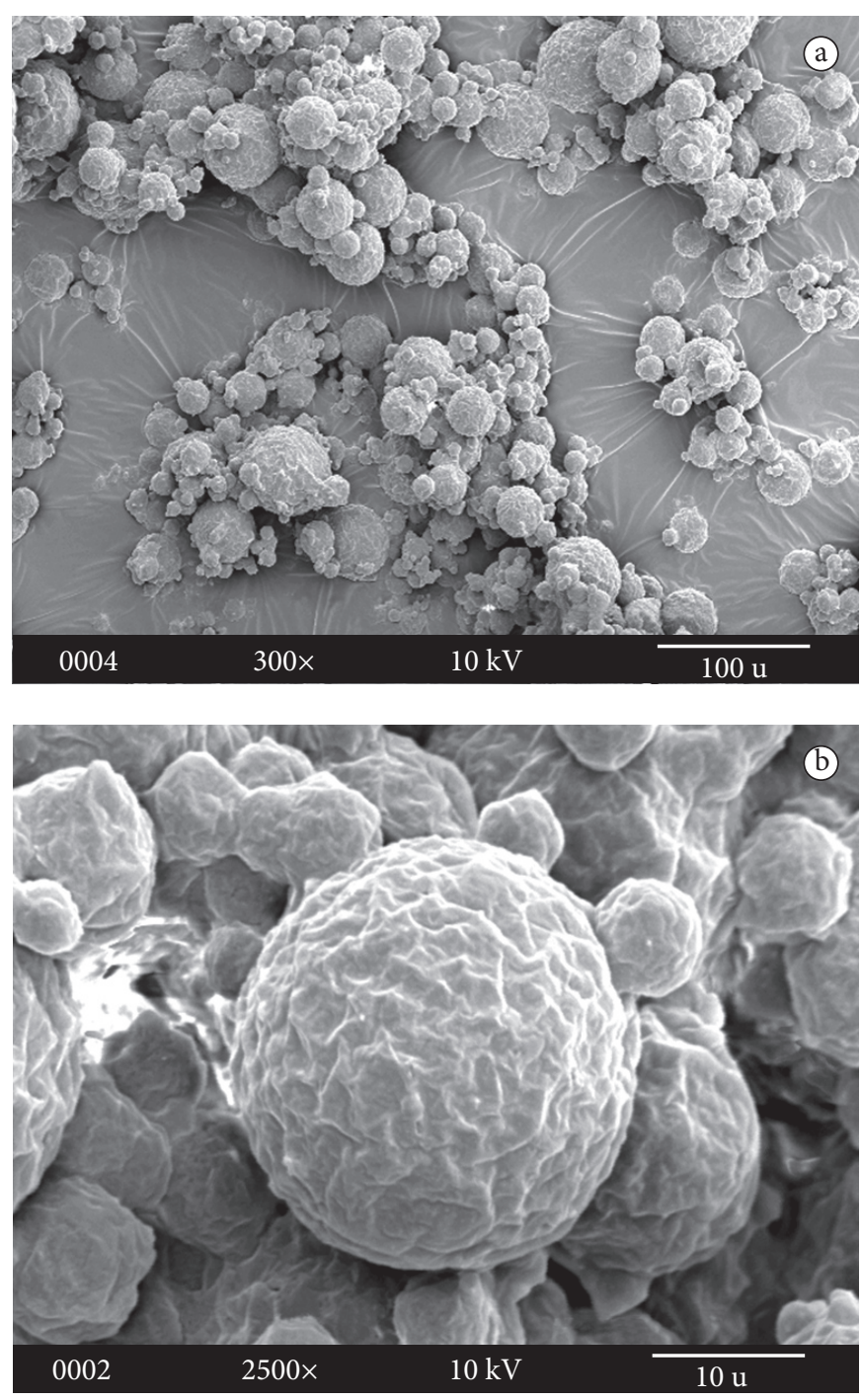

Figure 1. Micrographies of lipid microparticles containing glucose obtained by scanning electron microscope a) formulation $4(300 \times)$; and b) formulation $4(2500 \times)$. 
walls when the lipid matrix was composed of triestearine and behenic acid, also noting that the use of lecithin as surfactant in the formulations improved the continuity and homogeneity of the walls of microparticles. Although smooth walls have not been observed in the present work, more homogeneous surfaces were produced in comparison with microparticles in which sorbitan triesterate was used as surfactant in the encapsulation of a glucose solution (CHAMBI et al., 2008).

\section{Average size}

The average diameter of particles ranged from 25 to $32 \mu \mathrm{m}$ without significant differences $(\mathrm{p}<0.05)$ among the formulations used (Table 1). The standard deviations were between 9.9 and $13.4 \mu \mathrm{m}$ for the means of a minimum of 300 particles in the measure. Similar average sizes (26 to $30 \mu \mathrm{m}$ ) were previously attained for lipid microparticles containing hydrophobic core and produced using similar operational conditions (SAVOLAINEN et al., 2002).

The size deviations obtained seem to be inherent to the production method as corroborated by the surface morphology presented in Figure 1. Although different core material concentrations have been evaluated, these differences did not reflect as differences in the average size of the microparticles obtained.

\subsection{Evaluation of the performance of lipid microparticles}

\section{Superficial glucose and effective encapsulation efficiency}

The results of Table 2 show that formulations 3 and 6 , which were produced with glucose solutions of higher concentration $(80 \%)$, presented the highest values of superficial glucose (13.9 and $19.7 \mathrm{~g}$ of glucose.100 g $\mathrm{g}^{-1}$ of microparticles) indicated that glucose concentrations higher than $60 \%$ significantly increased core exudation on the surface of microparticles. On the other hand, when results are compared using the lipid/ glucose solution ratio as reference, little difference is observed between the proportions used (75/25 and 90/10), although the former contains a greater glucose amount (dry base) than the latter. These results indicate that greater core amounts can be encapsulated, avoiding exudation, by the use of a lipid/glucose solution ratio of $75 / 25$ with $60 \%$ concentration for the glucose solution.

The effective encapsulation efficiency (Table 2) obtained for the different formulations was high and ranged from 78 to $98 \%$. Magee Jr. and Olson (1981) obtained encapsulation efficiency between 80 and $90 \%$ in the encapsulation of glucose solution in lipid matrix containing milk fat and Span 60 and Glicomul as surfactants. Encapsulation efficiencies between 85 and 99\% were obtained by Zur Mühlen, Schwarz and Mehnert (1998) in the encapsulation of lipophilic cores in lipid matrix, using soy lecithin as surfactant. Hu et al. (2005) observed that, in lipid matrixes composed of stearic acid and different amounts of oleic acid, encapsulation efficiency increased from 47 to $70 \%$ as the proportion of oleic acid increased from 0 to 30 per cent in the matrix. The authors attributed this increase to the higher degree of disturbance in the lipid crystallization, thus increasing imperfections and creating more space for the core filling inside the lipid matrix.

Thus, the high effective encapsulation efficiency values (Table 2) obtained in this work may have been produced by several factors including the presence of oleic acid and lecithin, which may have hindered a more complete crystalline organization of the matrix during cooling, thus enabling the core to fill the interstices of the resulting lipid matrix. Moreover, the lecithin, as surfactant, may have helped to diminish the lipid repulsion in relation to the highly hydrophilic core used (JENNING; THÜNEMANN; GOHLA, 2000; MÜLLER; RADTKE; WISSING, 2002a, b; SCHUBERT; MÜLLERGOYMANN, 2005).

\section{Microparticles release profile}

As shown in Figure 2, all formulations presented instantaneous release, correspondent to the superficial glucose, followed by different release profiles throughout 120 minutes. The microparticles produced by the 40 and $60 \%$ glucose solutions, for both lipid/glucose ratios, presented excellent core retention. Less than $25 \%$ of glucose was released after 120 minutes. These formulations correspond to formulations

Table 2. Superficial glucose amount (\%) and effective encapsulation efficiency (\%) of microparticles attained by spray cooling.

\begin{tabular}{ccc}
\hline Formulations & Superficial glucose $(\%)$ & $\begin{array}{c}\text { Effective encapsulation } \\
\text { efficiency }(\%)\end{array}$ \\
\hline F1 & $5.5 \pm 0.8^{\mathrm{b}}$ & $78.3 \pm 7.2^{\mathrm{a}}$ \\
F2 & $6.7 \pm 0.5^{\mathrm{b}}$ & $93.7 \pm 4.6^{\mathrm{b}}$ \\
F3 & $13.9 \pm 2.1^{\mathrm{d}}$ & $85.9 \pm 2.9^{\mathrm{c}}$ \\
F4 & $2.6 \pm 0.3^{\mathrm{a}}$ & $97.8 \pm 4.0^{\mathrm{b}}$ \\
F5 & $2.9 \pm 0.9^{\mathrm{ab}}$ & $97.8 \pm 5.4^{\mathrm{b}}$ \\
F6 & $19.7 \pm 6.3^{\mathrm{c}}$ & $82.5 \pm 5.8^{\mathrm{ac}}$ \\
\hline
\end{tabular}

Equal letters, in the same column, do not present statistical difference at $\mathrm{p}<0.05$.

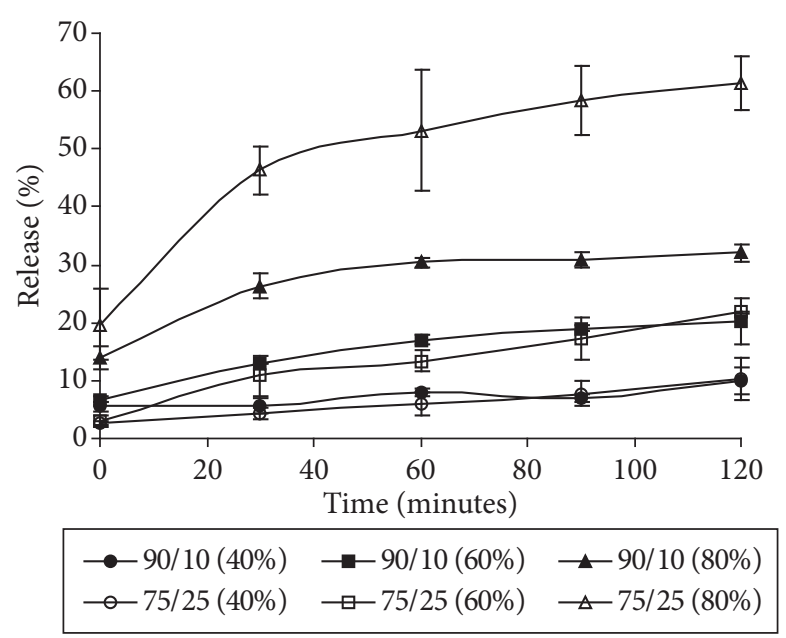

Figure 2. Glucose release (mean \pm standard deviation) of MpLs produced with different amounts of glucose. Legend: lipid/glucose solution ratio (glucose solution concentration). 
$1,2,4$ and 5, which presented the smallest values of superficial glucose (Table 2). On the other hand, the microparticles produced with glucose solution of $80 \%$ presented low core retention with a glucose release of $32 \%$ and $62 \%$ (after 120 minutes) for the microparticles produced with the lipid/glucose solution ratios of $90 / 10$ and $75 / 25$, respectively.

The presence of lipid mixture containing solid and liquid lipids must have contributed to disturb crystalline organization, retaining the core inside the lipid matrix and hindering its diffusion to the external aqueous medium. The retention capacity of encapsulated glucose solutions in lipid microparticles with lipid mixtures of solid-liquid fatty acids (stearic acid oleic acid) in relation to the lipid mixtures containing solidsolid fatty acids (stearic acid - lauric acid) has been recently studied, where better glucose retentions were attained when the stearic acid-oleic acid mixture was used as the wall material of microparticles (CHAMBI et al., 2008). Lecithin may have also acted synergistically with the liquid lipid fraction avoiding a higher degree of matrix crystalline structuring, thus increasing the loading capacity of microparticles and improving hydrophilic core material retention inside the particles (SCHUBERT; HARMS; MÜLLER-GOYMANN, 2006).

Figure 2 also shows that MpLs produced with lower core ratio had better release control (modulated and constant release) in relation to the microparticles produced with higher core ratio, where release tends to subtly and ultimately increase. The increase of glucose solution volume, in relation to the wall material, seems to destabilize the lipid matrix, thus leading to a much less controlled core release during the time evaluated.

The results indicate that core retention is significantly influenced by the glucose solution concentration, whereas release modulation seems to be influenced by the lipid/glucose solution ratio.

\section{Conclusions}

The microparticles attained presented spherical shape, with an average diameter ranging from 25 to $32 \mu \mathrm{m}$, and continuous but yet rugged walls, as a consequence of the use of stearic acid in the formulation. The effectively encapsulated core amount was dependent upon the glucose solution concentration used in the formulations. In a general way, the formulations studied presented high effective encapsulation efficiency (78-98\%), making the encapsulation of large amounts of liquid hydrophilic cores possible. For the best encapsulation efficiency (formulation $4-40 \%$ glucose solution, lipid/glucose solution ratio of $75 / 25$ ) only $10 \%$ of the core was released after 120 minutes. The lipid/ glucose solution ratio affected the release modulation, where a better release control was observed for the ratio 90/10. The amount of glucose released was influenced by the glucose solution concentration, where less than $25 \%$ of core was released after 120 minutes for the concentrations of 40 and $60 \%$.

\section{References}

AMERICAN OIL CHEMISTS SOCIETY - AOCS. Official methods and recommended practices of the AOCS. Champaign, 1990.
CHAMBI, H. N. M. et al. Solid lipid microparticles containing water-soluble compounds of different molecular. Food Research International, v. 41, n. 3, p. 229-236, 2008.

ELDEM, T.; SPEISER, P.; HINCAL, A. Optimization of spray-dried and -congealed lipid micropellets and characterization of their surface morphology by scanning electron microscopy. Pharmaceutical Research, v. 8, n. 1, p. 47-54, 1991.

HENRY, R. J.; CANNON, D. C.; WILKEMAN, J. Clinical chemistry, principles and techniques. 2 ed. New York: Harper \& Harper Row Publishes, 1974.

HU, F. Q. et al. Preparation and characterization of stearic acid nanostructured lipid carriers by solvent diffusion method in an aqueous system. Colloids and Surfaces B: Biointerfaces, v. 45, n. 3-4, p. 167-173, 2005.

JACKSON, L. S.; LEE, K. Microencapsulation and the food industry. Lebensmittel-Wissenschaft Technologie, v. 24, n. 4, p. 289-297, 1991

JENNING, V.; THÜNEMANN, A. F.; GOHLA, S. H. Characterisation of a novel solid lipid nanoparticle carrier system based on binary mixtures of liquid and solid lipids. International Journal of Pharmaceutics, v. 199, n. 2, p. 167-177, 2000.

KWAK, H. S.; IHM, M. R.; AHN, J. Microencapsulation of $\beta$-Galactosidase with Fatty Acid Esters. Journal of Dairy Science, v. 84, n. 7, p. 1576-1582, 2001.

MAGEE Jr., E. L.; OLSON, N. F. Microencapsulation of cheese ripening systems: formation of microcapsules. Journal of Dairy Science, v. 64, n. 4 , p. 600-610, 1981.

MASCHKE, A. et al. Development of a spray congealing process for the preparation of insulin-loaded lipid microparticles and characterization thereof. European Journal of Pharmaceutics and Biopharmaceutics, v. 65, n. 2, p. 175-187, 2007.

MEHNERT, W.; MÄDER, K. Solid lipid nanoparticles: production, characterization and applications. Advanced Drug Delivery Reviews, v. 47, n. 2-3, p. 165-196, 2001.

MELLEMA, M. et al. Wax encapsulation of water-soluble compounds for application in foods. Journal of Microencapsulation, v. 23, n. 7, p. 729-740, 2006.

MÜLLER, R. H.; RADTKE, M.; WISSING, S. A. Nanostructured lipid matrices for improved microencapsulation of drugs. International Journal of Pharmaceutics, v. 242, n. 1-2, p. 121-128, 2002a.

MÜLLER, R. H.; RADTKE, M.; WISSING, S. A. Solid lipid nanoparticles (SLN) and nanostructured lipid carriers (NLC) in cosmetic and dermatological preparations. Advanced Drug Delivery Reviews, v. 54, suppl. 1, p. S131-S155, 2002 b.

ÖNAL, U.; LANGDON, C. Characterization of lipid spray beads for delivery of glycine and tyrosine to early marine fish larvae. Aquaculture, v. 233, n. 1-4, p. 495-511, 2004.

RÉ, M. I. Microencapsulation by Spray-drying. Drying Technology, v. 16, n. 6, 1195-1236, 1998.

RIBEIRO DOS SANTOS, I. et al. Microencapsulation of protein particles within lipids using a novel supercritical fluid process. International Journal of Pharmaceutics, v. 242, n. 1-2, p. 69-78, 2002.

RODRIGUEZ, L. et al. Description and preliminary evaluation of a new ultrasonic atomizer for spray-congealing processes. International Journal of Pharmaceutics, v. 183, n. 2, p. 133-143, 1999.

ROSENBERG M.; LEE, S. J. Calcium-alginate coated, whey proteinbased microspheres: preparation, some properties and opportunities. Journal of Microencapsulation, v. 21, n. 3, p. 263-281, 2004. 
SAVOLAINEN, M. et al. Evaluation of controlled-release polar lipid microparticles. International Journal of Pharmaceutics. v. 244, n. 1-2, p. 151-161, 2002.

SCHUBERT, M. A.; HARMS, M.; MÜLLER-GOYMANN, C. C. Structural investigations on lipid nanoparticles containing high amounts of lecithin. European Journal of Pharmaceutical Sciences, v. 27, n. 2-3, p. 226-236, 2006.

SCHUBERT, M. A.; MÜLLER-GOYMANN, C. C. Characterisation of surface-modified solid lipid nanoparticles (SLN): influence of lecithin and nonionic emulsifier. European Journal of Pharmaceutics and Biopharmaceutics, v. 61, n. 1-2, p. 77-86, 2005.
SHAHIDI, F.; HAN, X. Q. Encapsulation of food ingredients. Critical Reviews in Food Science and Nutrition, v. 33, n. 6, p. 501-547, 1993.

WEISS, J.; DECKER, E. A.; MCCLEMENTS, D. J. Solid lipid nanoparticles as delivery systems for bioactive food components. Food Biophysics, v. 3, n. 2, p. 146-154, 2008.

ZUR MÜHLEN, A.; SCHWARZ, C.; MEHNERT, W. Solid lipid nanoparticles (SLN) for controlled drug delivery - drug release and release mechanism. European Journal of Pharmaceutics and Biopharmaceutics, v. 45, n. 2, p. 149-155, 1998. 